\title{
Typical Immoral Behaviour: Bluffing, Cheating and Looting in
}

\section{State and Society}

\author{
Jan-Erik Lane ${ }^{1 *}$ \\ ${ }^{1}$ Fellow with Public Policy Institute, Belgrade; 10 Charles Humbert, 1205 Geneva; 559A, 3rd Floor, \\ Thuya Street, 9th Quarter, Yangon, Myanmar \\ *Jan-Erik Lane, E-mail: janeklane@gmail.com
}

Received: April 13, 2017

Accepted: April 22, 2017

Online Published: May 4, 2017

doi:10.22158/jepf.v3n2p201

URL: http://dx.doi.org/10.22158/jepf.v3n2p201

\begin{abstract}
The development of theories of asymmetric information and of opportunistic behaviour is very important for understanding the increase in so-called affairs in capitalist democracies. The frequent occurrences of economically immoral behaviour in state and society call for mpre refined inquiries into various types of cheating and bluffing. Traditional economic theory only covered monopoly and collusion, but realistic political theory acknowledged the relevance of mmoral activities. Here we reject the naive approach, calling everything "corruption" and calling for moral rearmament to build up something as diffuse as "social capital". Distinguishing between petty and big corruption is the key for modelling economically immoral behaviour comparatively, as well as separating between defection, corruption, looting and bluffing.
\end{abstract}

\section{Keywords}

immoral action: cheating, corruption, looting, defection, logic of cheating, bonus culture society, Common Pool Regime (CPR), petty versus big corruption, CPI

\section{Introduction}

The cheating phenomena have always interested the political scientists, but only recently has economics taken up the topic to lengthy theorizing. Cheating occurs very frequently in state and market. But one should distinguish between a variety of cheating behaviour. Corruption constitutes a form of cheating, but there are many others. Consulting the standard dictionaries, one receives an unambiguously nice definition, common to all of them. Thus, we read versions of the following core: "Cheat: to break a rule or law usually to gain an advantage at something".

The definiens expression comprise a) break a rule or a law, and b) gain advantage. Thus, we can separate moral cheating in relation to a rule and legal cheating visavi the law. Whether it is the first or the second, the cheater acts rationally to gain something he or she could not otherwise have. This 
entails that the expected value of cheating must be larger than 0 as well as higher than the expected value of not cheating.

The logic of cheating was modelled in a brutal manner in Machiavelli The Prince, but he was accused of confusing the IS and the OUGHT, recommending or legitimating bluffing, reneging, corrupting, looting, etc. Although these types of behaviour are immoral, they need to be understood in the manner of positive social science. Bluffing, for instance, differ from cheating in that a convention or agreement is not the central point. But its relevance today has been shown by the manoeuvres of Putin, over-displaying the military might of Russia, while President Obama did not call uppn his bluffs in the Ukraine and Syria.

This paper discusses three forms of cheating, namely reneging in international coordination, corruption in poor and rich countries and the new form of looting in private enterprises and financial institutions, involving extreme pay and frimge benefits for CEOs_-bonus culture. We start to mention the fundamental G. Becker model of cheating behaviour at the micro level. And we end with a theory of the general rise of cheating in capitalist democracies: the bonus culture society.

\section{Cheating Behaviour}

Cheating is of course troublesome for social systems, as so much interaction is based upon agreements, promises or formal arrangements like treaties, etc. Defection is an option in all forms of cooperation or coordination, like S. Kierkegaard's two conceptual pairs: Either-Or: Comply or Renege? Game theory shows stunningly the force of reneging, once, repetitively or sequentially.

The multiple forms of cheating must fit into the Becker equations (1968) on rational micro behaviour. The benefits must outweigh the costs. But the cheater(s) can only have subjective estimates of these numbers, meaning that there are bound to occur misjudgements and mistakes about probabilities of success. Since the probability estimates of success or failure are subjective, they may be very far off the objective probabilities. However, cheaters update themselves in order to come closer to reality.

Cheating tends to become a repetitive behaviour, which allows for more accurate estimations. The costs involve the retaliation of other people, personal friends or the legal authority. Cheating can become very nasty for the cheater, for instance in insider trading or faked jobs. If the cheater is disclosed, the harm of his/her reputation may be very costly indeed. But there may also be high lawyer fees for defence.

The benefits may be substantial of course. It may be a one time bonanza or cheating may reap benefits in continuity. A successful cheater become accustomed to his success and keeps going until there is a reaction. Cheating may be rather innocent, as when a person reneges upon a small promise, or it may involve gigantic sums of money, as with insider trading or the rigging of contracts and bidding processes.

Cheating occurs in both government and their bureaux as well as in markets and enterprises. A spectacular example of the former was the housing cheat in Parliament, where several MP:s bent the 
rules about double residency in ugly manner. One of the most spectacular cases of private sector cheating was of course the Jew Bernie Madoff, who did not even hesitate to embezzle Jewish welfare agencies, supporting, e.g., Jerusalem University.

Prosecuting cheating tends to be cumbersome, as cheaters can often afford lawyers with great skills in questioning evidence. If a statesman accepts gifts, then so what? If a Premier employs his family on public jobs, so what? How to present proofs of insider trading, when it could be just accidental? Cheating is different from theft or murder, making it much more transaction cost heavy to identify and punish. And accusation of cheating are often countered by litigation, again costly transactions.

When cheating takes place in a game of coordination based upon cooperation and promises thereof, we say the cheater commits defection or reneging. The famous model of the PD game is about defection and has been analysed at great length in all kinds of versions: one shot game, repetitive game, finite repetition and with infinite horizon. Defection may occur by one player or both players in a two person situation, but PD games may also involve ocean games, the larger the game the less likely is coordination success. In finite games, reneging is always the sub game perfect Nash as long as there is not outside enforcement.

In the new developments in game theory assuming asymmetric information, two new types of cheating emerge: shirking and pretending. These forms of cheating refer to long-run contracts in principal-agent gaming, where the agent cheats either ex post or ex ante. These concepts are useful in analysing the phenomenon of bureaucratic inefficiency and firm looting.

\section{Defection}

The coordination masterminded by the UN concerning global warming, the many COPs and the UNFCCC institution, runs with a great risk of one form of cheating, namely defection. If a small poor country reneges, it is no big deal, because emissions are a function of the size and affluence of an economy. The COP21 Treaty is an Elinor Ostrom Common Pools' Regime (CPR), covering the entire world. Her argument was that CPR:s may work despite the rational response to PD games, namely defection, at least in the last round of play—backwards induction. Now, the US has decided to renege upon the COP21 Agreement, which will destroy much of the coordination effort, as other nations will be tempted to defect too. The size of US emissions is second only to that of China. And other nations like Australia, South Korea and Japan may be tempted to do the same. Let us look at the energy-emissions problematic from the point of view of US defection. It is in fact not at all forced by the circumstances, as with other countries where alternatives hardly exist.

At the end of the day, some countries may simply renege upon the COP21 goals of decarbonisation. They may feel they cannot afford such an immense energy transformation., at least not without massive assistance the so called Super Fund.

The US is a major carbon polluter, both in aggregation and per person. Figure 1 shows its dependence upon fossil fuels. 
United States Primary Energy Consumption by Source (2015)



Figure 1. Energy Mix for the US

Yet, the positive signs for the US include a downward sloping curve in Figure 2. But as solar power and wind power expands, so atomic power is reduced and shale oil and gas are augmented. Yet, politics is decisive here, as the US now reneges upon the COP21 decarbonisation goals.

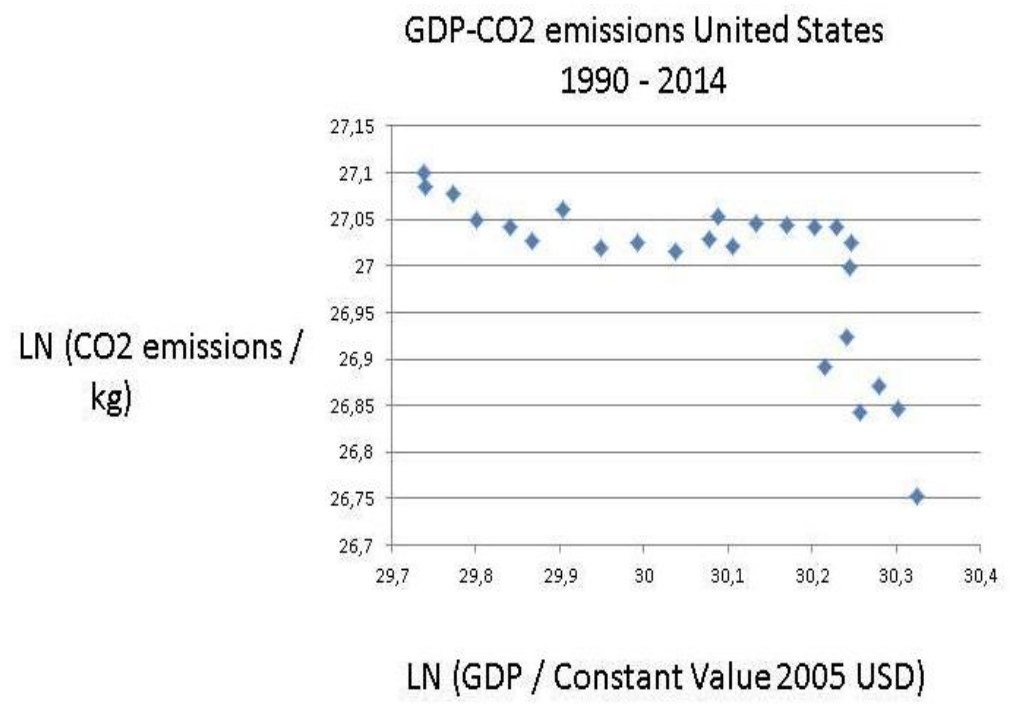

Figure 2. USA: Link GDP-CO2

Developments in the US have been looking promising lately, as most countries display upward sloping GDP-CO2 links. But to comply with the draconian COP21 goals, the US would have needed to do much more in terms of reducing fossil fuels, increasing renewables or restart with nuclear power. Now the Trump administration defects, which just reflects that there is no clear and consistent energy policy in the US. 
With regard to global warming, the entire globe is a common pool (Ostrom, 1990), but Ostrom's solution to free riding - the Common Pool Regime (CPR) - simply does not work, especially not for ocean games. Her argument that CPR may even work concerning small groups, due to informal or social pressure, is questionable, as also these communities would call in the state against defections somehow directly or indirectly.

\section{Stylised Heralded View of Corruption}

In much of the literature on corruption (see e.g., Bowles, 1999; Holms, 2015), one finds the following standard tenets:

a) There is massive corruption over the whole world, causing lots of negatives;

b) The corruption in Third World countries is much higher than in the First World, counting the Second World to the Third World;

c) Public sector corruption is more wide-spread and dangerous than private sector corruption.

Let me quote a typical generalisation about corruption from an encyclopaedia with the entry "corruption":

"In the world's worst offending countries, corrupt government officials steal public money and collude with businesses to sell laws, rules, regulations, with and government contracts. The World Bank reports that "higher levels of corruption are associated with lower per capita income" (World Bank, 2001, p. 105; Melese, 2002).

Yet, embezzlement is nor the same as corruption. And collusion between government and the private sector occurs in many countries, not only the "world's most offending countries". Just reflect over all the pressure groups and the Political Action Committees (PAC) in Washington, DC. The PACs fund the incredible election expenses of candidates and legislators, but how to confine these millions of dollars to non-private spending? And what is the implicit quid pro quo when a whole industry supports a candidate or his family, like oil and Bush? One must be more specific about the concept of corruption and model how it may occur in poor and rich countries-directly and indirectly, and whether it is a matter of petty or big corruption: R.A. Posner states: "The Real Corruption Is the Ownership of Congress by the Rich" (https://www.promarket.org/richard-posner-real-corruption-ownership-congress-rich/).

The well-known Transparency Index targets perceived (!) corruption, which is a quite different entity compared with real corruption, according to the more specific concept above. CPI will include whatever the experts in the panel asked state. Thus, it is likely that these expert estimates cover most of the above listed abuses under the heading "perceived corruption".

Perhaps this is the only research approach possible, when it comes to country comparisons? The CPI states the following definition of "corruption": "Corruption is the abuse of entrusted power for private gain. It can be classified as grand, petty and political, depending on the amounts of money lost and the sector where it occurs". 
Source: http://www.transparency.org/what-is-corruption/

This amounts to a most wide concept of corruption, but focusing only upon government and its bureaucracy. Perhaps it is both too wide and too narrow as a definition? This is not the place to question the individual country rankings, but some scores are a little stunning, like for all countries in the Balkans, Latin America in general and Tunisia. Both the validity and the reliability of the transparency index may be criticized. How to know whether one African or Asian country is more corrupt than another?

This concept of corruption covers all forms of abuse of public power for private gains - see the above list. Thus, it would be more appropriate to speak of CPI as an index of "economic crimes in government".

The perceptions of average economic crimes come from a panel of experts with some international organizations. We read in Wikipedia the following: "Transparency International commissioned Johann Graf Lambsdorff of the University of Passau to produce the Corruption Perceptions Index (CPI). The 2012 CPI draws on 13 different surveys and assessments from 12 different institutions. The institutions are the African Development Bank, the Bertelsmann Foundation, the Economist Intelligence Unit, Freedom House, Global Insight, International Institute for Management Development, Political and Economic Risk Consultancy, Political Risk Services, the World Economic Forum, the World Bank and the World Justice Project".

Perhaps the country rankings from 0 to 100 were averaged out for these expert groups? We do not know what materials they employed for the rankings, from much corruption to no corruption.

Let us look at the average continent scores for 2015 (Table 1).

Table 1. Amount of Transparency in the Public Sector = Average Lack of Corruption Numbers

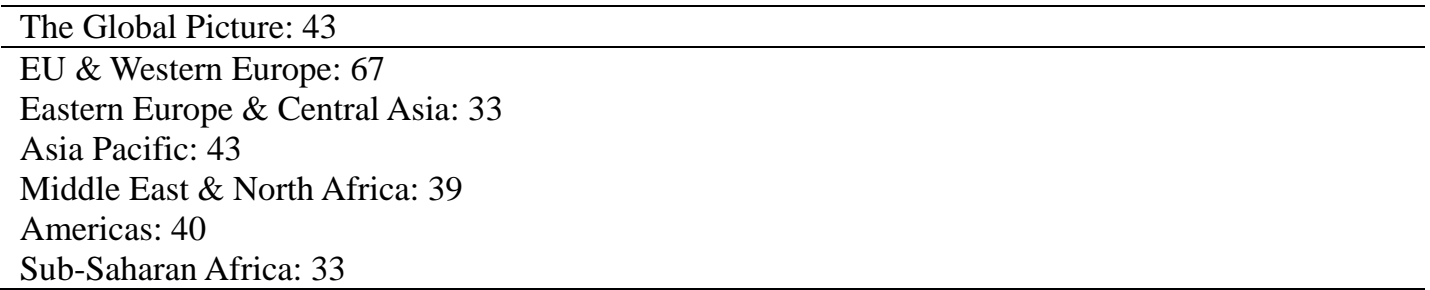

Source: https://www.iaca.int/images/news/2016/Corruption_Perceptions_Index_2015_report.pdf

Actually, these average scores do not say much, as the group categories are extremely wide. The span within some groups is quite large, meaning that the category continent explains little. "Americas" comprise both North, Central and South America, although their scores vary much. Let us try affluence first and foremost. The same applies to "Asia Pacific".

Figure 3 shows instead in a clear fashion that these CPI scores are linked with affluence as GDP per capita. 


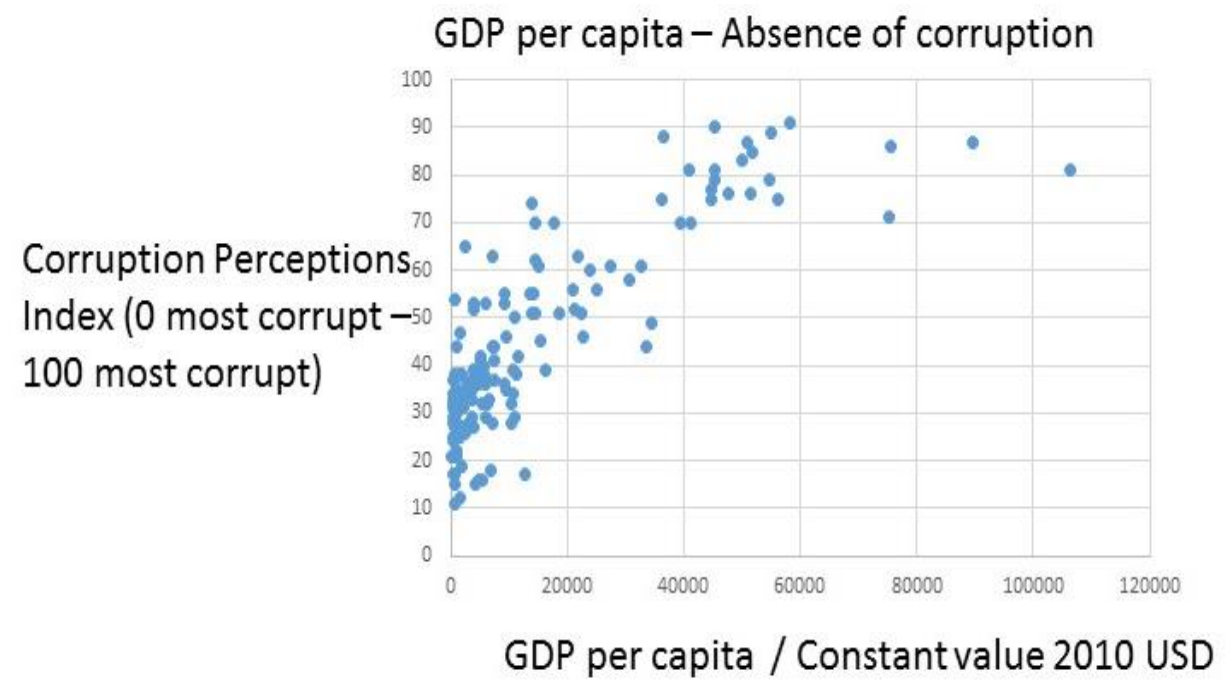

Figure 3. CPI and GDP Globally: $y=0,0008 x ; R^{2}=0,68$

Sources: Corruption Perceptions Index 2015. Transparency International, http://www.transparency.org; World Bank national accounts data; OECD National Accounts data files.

The finding in Figure 3 is an asymptotic curve, meaning that over a certain threshold of affluence, the lack of corruption is established and transparency not augment with more GDP. This magical threshold seems to take place at 4000-6000 US dollar per capita, which is maybe an income that makes a person less eager to supply corrupt services—see the demand — supply model below.

Examining Figure 3, one is inclines to argue that the CPI measures government abuse in general, and not merely corruption. If one includes all kinds of personal abuses by politicians and bureaucrats, one arrives at the conventional view that public sector criminality is higher in the Third World countries than in the First World countries. But is this really specifically corruption as bribery, covering the entire society, also the market sector? Or is it merely the occurrence of general crime against the state in poor countries?

Is the standard inherited view on crime correct? One may consult other indices that tap the respect for the law and contract enforcement in general, like the rule of law index in the big World Bank Governance project. In the major WB Governance project, the authors make a distinction between the rule of law on the one hand and control of corruption on the other hand. They state: (1) "Rule of Law (RL) - capturing perceptions of the extent to which agents have confidence in and abide by the rules of society, and in particular the quality of contract enforcement, property rights, the police, and the courts, as well as the likelihood of crime and violence". (2) "Control of Corruption (CC) - capturing perceptions of the extent to which public power is exercised for private gain, including both petty and grand forms of corruption, as well as 'capture' of the state by elites and private interests" (Kaufmann, Kraay, \& Mastruzzi, 2010).

The CC index is evidently very much the same as the CPI, i.e., extremely broad, covering all kinds of Published by SCHOLINK INC. 
public abuse for private gain. The WB Governance project state that they made use of the Transparency Index when calculating the $\mathrm{CC}$ index.

However, what is troublesome is that the RL index in reality turns out to be much the same the CPI index, i.e. measuring the backwardness of the Third World. Figure 4 shows the link between WB's rule of law index and Transparency International's CPI. They measure the same phenomenon, namely the link between economic criminality and poverty.



Figure 4. CPI and WB: RL; $R^{2}=0,94$

Perhaps then, the RL index by the WB Governance project is also a Third World index? Look at Figure 5 for the same curvature, very low scores in poor nations and then an augmentation up to a certain level, an asymptotic curve. But the CC or CPI was measured independently of the RL index!



Figure 5. GDP—Rule of Law (WB): $R^{2}=0,6485$ 
One may pursue this finding one step further, by looking at the link between the GDP scores and the so-called World Justice index. It is calculates thus: “The WJP Rule of Law Index relies on over 100,000 household and expert surveys to measure how the rule of law is experienced in everyday life around the world. Indicators are grouped around the following nine factors" ... "Performance is measured using 44 indicators across eight primary rule of law factors, each of which is scored and ranked globally and against regional and income peers: Constraints on Government Powers, Absence of Corruption, Open Government, Fundamental Rights, Order and Security, Regulatory Enforcement, Civil Justice, and Criminal Justice".

Source: http://www.worldjusticeproject.org/rule-of-law-index

The World Justice Project out of Washington DC covers not only corruption or rule of law but criminality at large at arrive at the picture as the CPI index, namely.

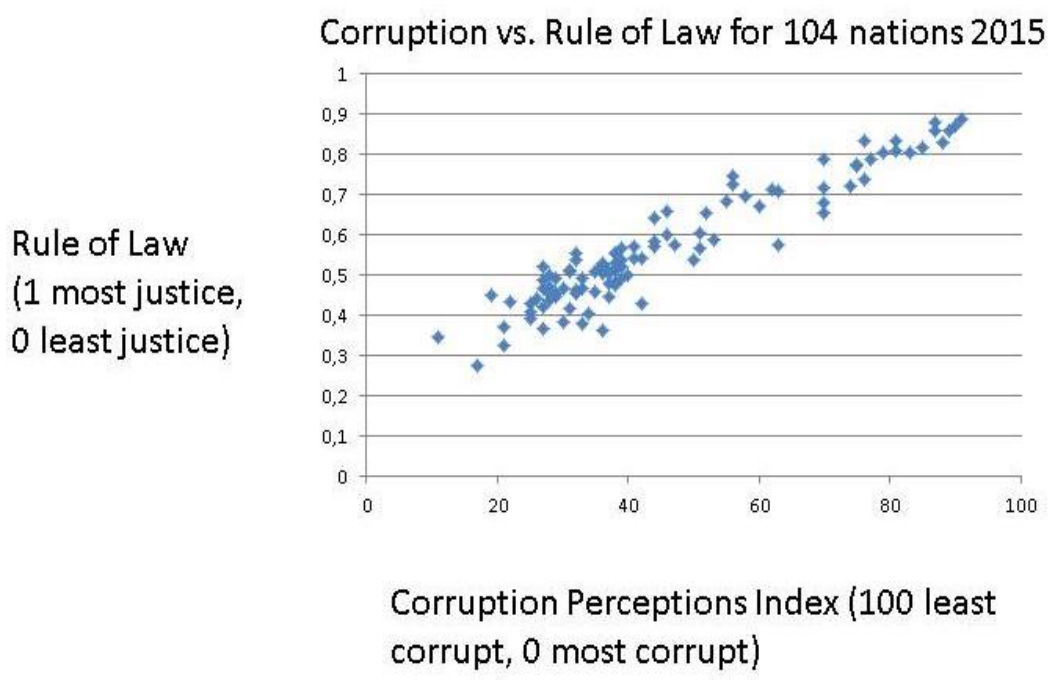

Figure 6. CPI and Rule of Law (WJP): $y=0,0069 x ; R^{2}=0,90$

Source: Corruption Perceptions Index from Transparency International, http://www.transparency.org;

World Justice Project, http:// www.worldjusticeproject.org

\section{Concept of Corruption}

We hear daily about accusations of corruption in politics and economics. One may be led to believe that corruption is very widespread and impacts upon social outcomes in a broad manner. But what is corrupt behaviour? And does it matter so much for outcomes everywhere?

The often cited index of transparency (CPI) is claimed to constitute the index of corruption. We cite: "Corruption takes many forms, but always involves the abuse of entrusted power for private gain" (http://www.transparency.org). This definition of "corruption" is both too broad, including all forms of government or bureaucracy abuse, and too narrow, excluding the private market sector. It is not a very telling index. We need to go beyond the conventional framework of analysis, based upon the Transparency Index, which actually is heavily skewed against poor countries, or the Third World. 
First we need a concept of corruption that is specific and does not denote any crime or abuse. Second, we must revise the stylized and inherited picture that corruption is mainly a set of Third World phenomena. It is vital to distinguish between two types: petty corruption and big money corruption.

It should be acknowledged from the outset that data is sparse of obvious reasons. To find actual information about specific cases of corruption, one would need access to lots of legal rulings and processes comparatively. Thus, what follow below is mainly some theoretical notes and conceptual deliberations.

The occurrence of corruption is a hot topic of research now, but what is the meaning of the word "corruption"? A theory of corruption in society with comparative implications has to start from conceptual considerations, separating between various forms of economic vices. One can criticize the approach of Transparency International with its corruption perceptions index that it covers all kinds of public vices but leaves out private sector corruption. The specificity of corruption should be emphasized, underlining implicit contract consideration with a quid pro quo. The approach to corruption as bribery or kickbacks in Law and Economics with R.A. Posner is not consistent. The distinction between petty and big corrupt practices is crucial for understanding the role of bribery in society.

\section{1 "Corruption"}

One may use various sources for a small scale enquiry into the semantics of "corruption". Here, we go to a few standard dictionaries, like first the Oxford Thesaurus:

"SYNONYMS: dishonesty, dishonest dealings, unscrupulousness, deceit, deception, duplicity, double-dealing, fraud, fraudulence, misconduct, lawbreaking, crime, criminality, delinquency, wrongdoing, villainy, Bribery, bribing, subornation, venality, graft, extortion, jobbery, profiteering, North American payola Informal crookedness, shadiness, sleaze, palm-greasing, Malfeasance, misfeasance, archaic knavery, rare malversation. Antonyms: Honesty".

Source: https://www.en.oxforddictionaries.com/thesaurus/corruption

Reading this long list, one immediately gets the impression of semantic chaos. "Corruption" has several and different meanings and the claim to synonymy is unclear if not unfounded. One may wish to separate between the following concepts:

- $\quad$ Crime

- $\quad$ Misconduct

- $\quad$ Dishonesty

- $\quad$ Fraud

- $\quad$ Bribery (illegal kickbacks)

- $\quad$ Unscrupulousness

- $\quad$ Extortion

- $\quad$ Malfeasance

These concepts are definitely not the same or identical, reducible to one common foundation, i.e., Published by SCHOLINK INC. 
corruption. A crime like manslaughter does not entail corruption, misconduct does not imply corruption, dishonesty neither nor fraud. On the contrary, bribery entails corruption. For unscrupulousness, extortion and malfeasance holds the same, i.e., no necessary link, only contingency. No small wonder that people write that if corruption is stopped, then big wonders arrive.

Corruption is a sufficient condition for crime, misconduct, dishonesty, fraud and malfeasance, but it is definitely not a necessary condition. In a definition, we would like to cite both necessary and sufficient conditions. Approaching the definition of the concept of corruption, one may travel along the broad route above, but it makes the concept too broad or hollow. Only bribery is an essential property of corruption, in my view.

\subsection{Public and Private Sector}

If the Oxford Thesaurus presents a too broad definition, the perhaps the Oxford Dictionary holds a too narrow definition. First, it presents the adjective "corrupt":

Having or showing a willingness to act dishonestly in return for money or personal gain: "unscrupulous logging companies assisted by corrupt officials";

Then the Oxford Dictionary goes on to present a definition of the work "to corrupt":

Cause to act dishonestly in return for money or personal gain: "there is a continuing fear of firms corrupting politicians in the search for contracts".

Source: https://www.en.oxforddictionaries.com/definition/corru

Here, the concept of the bribe is essential, but there is no reason to limit its use to the public sector, i.e., politicians and bureaucrats. The bribe or kickback knows no borders, public or private. But the bribe is the essence of corruption, establishing a link between the person who somehow pays and the person who in some manner receives, making both legally or morally culpable — a binary relationship.

Thus, corruption is a relationship, a binary word according to logic. One person supplies something valuable that the other person demands for a service or good. Thus, corruption binds two persons together in a quid pro quo, which is essential. Following this conceptual development, we must inquire into the definition of the term "bribe" to distinguish it from natural gift or ordinary payment, which actually is quite tricky. Perhaps it can only be done inside the court-room, as outside of court it could be just an accusation. This emphasis upon:
a) Binary interaction
b) Dishonest favour
c) Illegal payment

Makes it possible to identify a specific concept of corruption. And, importantly, one can distinguish the term from other terms, like the following.
i) Embezzlement
ii) Favouritism
iii) "Concubinage"
iv) Patronage 
v) Cronyism

vi) Money laundering

vii) Tax evasion

viii) Insider trading

ix) Fake public job

All these phenomena may contingently involve the bribe, i.e., corruption, but it is not a necessity. Embezzlement falls under the concept of theft, whereas the other forms of may involve reciprocity between the favourite and the giver of favours, but it is not necessary. These relations may be one directional and involve no bribe. Having clarified the concepts of corruption and their differences, one faces the difficult task of measuring the occurrence of specific corruption as bribery, as contract “consideration" between two individuals or two organizations, represented by individuals.

\subsection{Bribes: Payments or Gifts}

Corruption as bribery is nothing but a tacit contract between two parties where the key element of consideration is kept or must be kept secret.

In contract law consideration is concerned with the bargain of the contract. A contract is based on an exchange of promises. Each party to a contract must be both a promiser and a promisee. They must each receive a benefit and each suffer a detriment. This benefit or detriment is referred to as consideration. We cite again:

"Consideration must be something of value in the eyes of the law-(Thomas v Thomas) (1842) 2 QB 851. This excludes promises of love and affection, gaming and betting, etc. A one sided promise which is not supported by consideration is a gift. The law does not enforce gifts unless they are made by deed".

Source: http://www.e-lawresources.co.uk/Consideration.php

In a corrupt deal, the consideration is neither explicitly written down nor is it kept open to others. And following Kant's publicity rule, that what is not capable of being revealed publicly is most probably illegal or reprehensible. A consideration binds both parties to deliver something agreed upon. Thus, there is a binary relation involving a quid pro quo. The promisee pays something of value and the promiser delivers a service.

Now, this is a narrow concept of corruption, but it is certainly not restricted in its application to the public sector. The crux of the matter is that the consideration involves the buying and selling of something that is not legally for sale. When proving corruption, it is vital to show that there was consideration about something that cannot be sold, which is not always easy to find evidence for.

Now, how widespread is corruption according to this strictly defined and narrow concept? I would suggest that it is hardly as widespread as claimed, although culture and legal tradition matters. Of course, poverty would be a strong motivation to supply corruption. Poverty may also be a factor on the demand side, but corruption may be expensive. In an economic approach to the demand and supply of corruption, one must start from the benefits and costs of the individuals involved in this binary 
transaction, the bribe. In addition, the cost of being caught in the act has to be taken into account.

Interesting cases of corruption arises when the accused of supplying a service defends himself/herself that it was only a matter of a gift without consideration. Consider the examples of Giscard d'Estaing and Olmert and Netanyahu in Israel.

Gifts as bribery is tricky, as the quid pro quo may be released a long time after the transaction. Payments as bribes may be negative, as when the consideration involves buying a good (e.g., property) as a much lower price than going market price.

\subsection{Ambiguity of the Gift in Politics and Public Administration}

The gift may be an invitation to corruption in the sense of bribery here, but it could also just be a token of sympathy. To prove corruption, one must show the quid pro quo, actual or expected. We are here on the demand side of corruption as a binary relationship, and the gift may constitute a legitimate expectation of some counter offer from the supply side of corruption. When a major politician like the French president or the Israeli Premier receives large valued gifts, then that calls for corruption inquiry. To whom belongs the gift? Is it personal or public? Is there any consideration involved, now or in the future?

In Singapore, known for its stern fight against corruption, gifts to public officials are not really allowed, due to the fact that giving may raise expectations. The regulations about corruption include a strict awareness of the problematic of the gift - one-sided or two-sided. Let us quote about corrupt intent and gift restrictions:

\subsubsection{Quid Pro Quo}

"Under Singapore law, on satisfaction of the "public body" test, there is no need to prove that the receipt of gratification was an inducement for a specific corrupt act. It is sufficient for the gratification to be given in anticipation of some future corrupt act. However, the accused must have corruptly accepted the gratification, i.e., believing that it was offered as an inducement, before this presumption is triggered. Case law refers to the sense of obligation the receipt of the gratification must create in the recipient. The relationship has been characterised by the courts as the purchase of the recipient's "servitude", establishing a "retainer" relationship and the accused being "beholden to" the giver".

\subsubsection{Gift Threshold}

Although there is no specific guidance on monetary thresholds of gifts in Singapore law, practical guidance can be found in the approach of public bodies. The Instruction Manual, published by the Singapore Government, which applies to all Singapore public officials, details when gifts and entertainment can be accepted and when they must be declared. As a matter of practice, all gifts need to be approved by a permanent secretary and only gifts under $\mathrm{S} \$ 50$ can be accepted. Any gifts valued at more than S\$50 can only be kept if they are donated to a governmental department or independently valued and purchased from the Government. Taking a slightly different approach, Tey's case revealed that the NUS Policy on Acceptance of Gifts by Staff requires consent to be sought for all gifts over S\$100. 
Source: http://www.nortonrosefulbright.com/knowledge/publications/102621/anti-corruptiondevelopments-in-Singapore

\subsection{Politics of Corruption}

The broad definition of "corruption" lends itself very well to political gaming. In some countries, accusation of corruption are legio, but one does not know whether it is corruption as bribery or corruption as any crime against the state, like embezzlement, favouritism or patronage. Often these accusations are merely politically motivated and enter into a blame game, where corruption accusations are traded among opponents.

Not many accusations of corruption end up in court, and even fewer result in punishments or incarceration. Proving real corruption, one has to give evidence about the parties involves, the consideration at the centre of the interaction and the following quid pro quo realization. Often, in these political debates about "corruption", what is meant is favouritism or embezzlement. This seems to be case for Brazil, where giant firm Petronas is said to have provided gifts, like luxury apartments (e.g., Lula), although this is difficult to prove, instead of naming all kinds of bad economic behaviour in the public sector "corruption", it is better to focus upon the specifics in each case. If it is corruption and not solitary embezzlement or group patronage, then what is the bribe in question? If it is a matter of a general relation of symbiosis, like in cronyism or favouritism, then it is more clarifying to speak of these phenomena directly than place them under "corruption".

Corruption has a strong illegal connotation, which is lacking in general favouritism. One may even argue that moral accusations of corruption can only be validated by court action. Yet, this would limit the application of the concept too much, because court systems in various countries possess different qualities in terms of the rule of law. Failure to punish corruption does not prove innocence, but it may merely be a matter of lack of evidence or court competence.

\subsection{Why Condemn Corruption}

Basically, the rejection of corruption whether in the public or the private sector has to be grounded on some fundamental concept governing social interaction or social systems at large. Political scientists adduce justice, whereas economists argue that efficiency holds the key to forbidding corrupt practices. Jurisprudence would side with the political scientists, although admitting that law varies from one country to another. But Law and Economics would claim that also jurisprudence would at the end of the day side with Posner's wealth maximization criterion, i.e., economic efficiency.

The justice argument against corruption focuses upon justice as impartiality or justice as formal equality, buttressed by several theories (Rawls, 1971; Raz, 2009), However, when justice is interpreted as real equality (Dworkin, 2000; Barry, 2005), then the implications of justice for corruption are less clear. The economic argument against corruption from Law and Economics is more complicated, as it depends upon various contingencies, like investments, rent-seeking, etc. 


\section{Outline of a New Approach}

The image of global corruption typically rendered on the basis of the index of transparency is too blunt, placing most corruption with Third World countries under a most general definition of "corruption" as public sector abuse for private gain. Targeting the concept of corruption as bribery, one may construct a more nuanced picture where corruption in the First World is fully recognized on the one hand and corruption in the Third World is better understood as mostly petty corruption on the other hand.

\subsection{Opaqueness of Private Sector Corruption}

The Transparency Index deals only with the abuse in the public sector. This is a major limitation, because in the private sector the opportunities for abuse are more numerous and much more difficult to spot and correct. Two reasons for this may be identified:

- $\quad$ The rules are less clear and enforceable;

- The spirit of collusion typical of private sector governance often hinders full scale revelations of abuse.

In the market sector with huge multinational enterprises and financial institutions, there is plethora of remuneration types that can be employed in the grey zone between legality and illegality. The amount of money for compensation is often staggering, with so-called bonuses reaching over 100 per cent of normal salary. Another opaque concept besides the ambiguous "bonus" (for success or mediocrity?) that may invite corruption is the "commission" in market dealings. During the last decade, the salaries, firing and pension deals of CEO:s have sky-rocketed to a level that indicates market failure, i.e., a lack of competition in the bidding process for these jobs.

The CEO may often count upon support from the board of his firm for large salary increases, regular or ad hoc, because he/she may suggest at the same time huge augmentations of board members' remuneration - perfect collusion against shareholders or stakeholders.

\subsection{Principal-Agent Gaming}

Some forms of corruption adhere to the principal-agent model, where an employee uses corrupt practices to go behind his/her principal to get extra revenue in an illegal manner, more or less tacitly. As public employee is bureaucracies in the Third World have a very low income in general, the supply of services or goods for bribes is huge. Similarly, as the quantity and quality of public services is low in poor countries, there is a large demand for improvements that may be the quid pro quo of a bribe.

\subsection{Big Versus Petty Corruption}

Poverty feeds crime. That is the conclusion one draw from the above Figures. But one knows not much about corruption in its more strict meaning as bribery. Theorizing corruption in a more strict definition as a binary relationship concentrated upon the bribe, one cannot assume that it occurs much more often in poor than in rich countries. It is vital to separate petty corruption from big corruption.

Petty corruption is often occurring in Third World countries. Why? Poverty! Often salaries of public officials are low, or they may not have been paid full salaries for some time. One can analyse petty corruption as a market phenomenon, where the buyer and seller meets, given their ambition to 
maximize expected value. The bribe has an additional cost or benefit, namely the risk of disclosure and loss of work or punishment.

The occurrence of corruption in Third World countries reflects their poverty and it is mainly a matter of petty bribery of low paid officials. The difference between the Third World and the First World may be visualized in a demand and supply framework (Figure 7).

Some may question the ambition to subject corruption to a demand and supply type of analysis. It could smack of economic model imperialism, as with Becker's framework (2013) or like the ideas of an economic analysis of law with Posner (2004). Yet, the aim here is just conceptual, i.e., to pin down a more precise concept of corruption and offer a reasonable theory of the difference between First World and Third World corrupt practices.

It is of course possible to speak of demand and supply of corruption, since there is the typical element in a contract between two parties, viz. the consideration. On the one hand, the promiser offers something and the promisee receives something and on the other hand there is the contra exchange of something valuable. There may be defection, but it would have to be settled outside of court, by means of retaliation.

One has to add the potential legal costs to the calculation of benefits and costs in corruption. It is a probability assessment that lies at the core of offering and taking bribes, but it is a question of subjective probabilities that may be completely wrong. In petty corruption, the probability of an incarceration must be taken into account somehow, whereas in big corruption the reputation costs could be enormous for a business. See Figure 7 for a simple model.

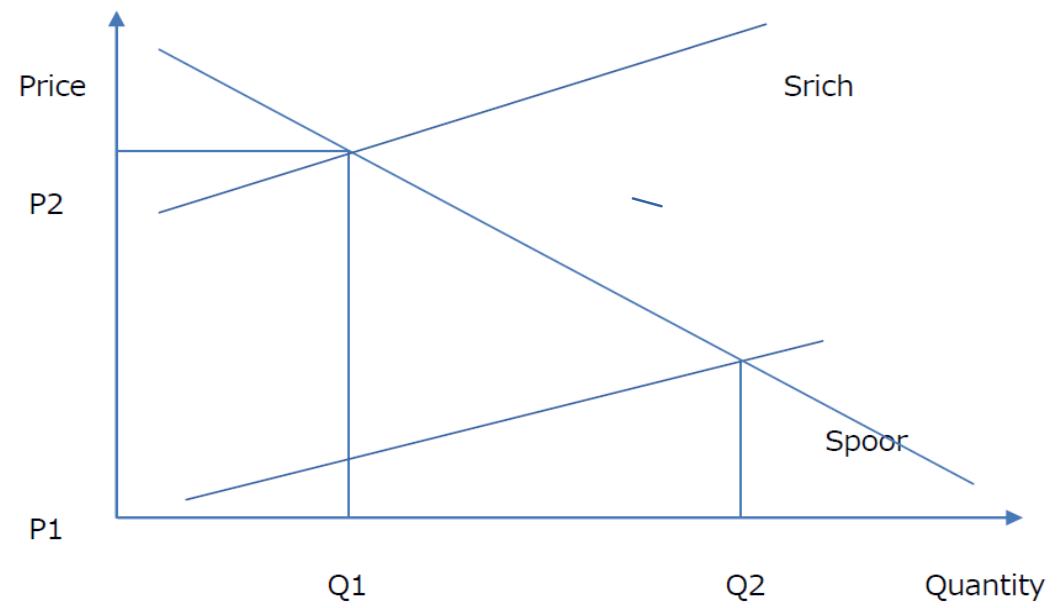

Figure 7. Demand for and Supply of Petty Bribes in Poor Societies (Q2) and Rich Societies (Q1)

The supply of petty bribes will be highly restricted in rich societies, because officials are paid decent remuneration and fear much the legal consequences of revelation. The demand curve is the same.

\subsection{Omnipresence of Big Corruption}

When it comes to big corruption, then each society comprises a clientele who dares to engage in such 
activities, focussing upon millions or billions of dollars. Here it is the demand curve that differs between the poor and rich country.

Big corruption is not often of the principal-agent gaming kind, but involves organisations, buying for licences or contracts. Kickbacks often take this form, where an organization promises to do some extra favours for the state, if awarded the deal. A firm may also pay an employee an astonishingly high bonus, if he/she can get hold of the contract in question. Sometimes firms operate a whole system of bonuses that far outweighs the normal salary in order to create inducements. Whether this is legal or not is a question for the grey-zone, but the temptation for the individual employee to fix the deal may become too tempting.

One has recorded several cases of firm corruption in defence procurement as well as in the competition for, e.g., Telecom contracts or defence procurement. Rose-Ackerman (2016) argues that corruption has increased, but are we talking about big or petty corruption, corruption as bribery or kickback or merely economic crimes against the state?

Rose-Ackerman presents an analysis along Chicago School Economics of corruption as resulting from the incentives of public officials. She suggests numerous reforms to "reduce the incentives for bribery and increase the costs of corruption", reminding of Becker's famous analysis of crime- "three strikes and you are out".

Yet, why care about petty corruption? Big corruption is different, violating for instance the World Trade Organisation's rules for public procurement. In petty corruption like in Nigeria, bureaucrats often simple try to stay alive, sometimes not paid or paid properly. Big corruption occurs in the summit of states and markets, but it is not the same as, e.g., embezzlement, patronage or money laundering.

An accusation of big corruption must provide evidence of mutual consideration, involving some form of bribery or illegal kickback. See Figure 8 on big corruption.

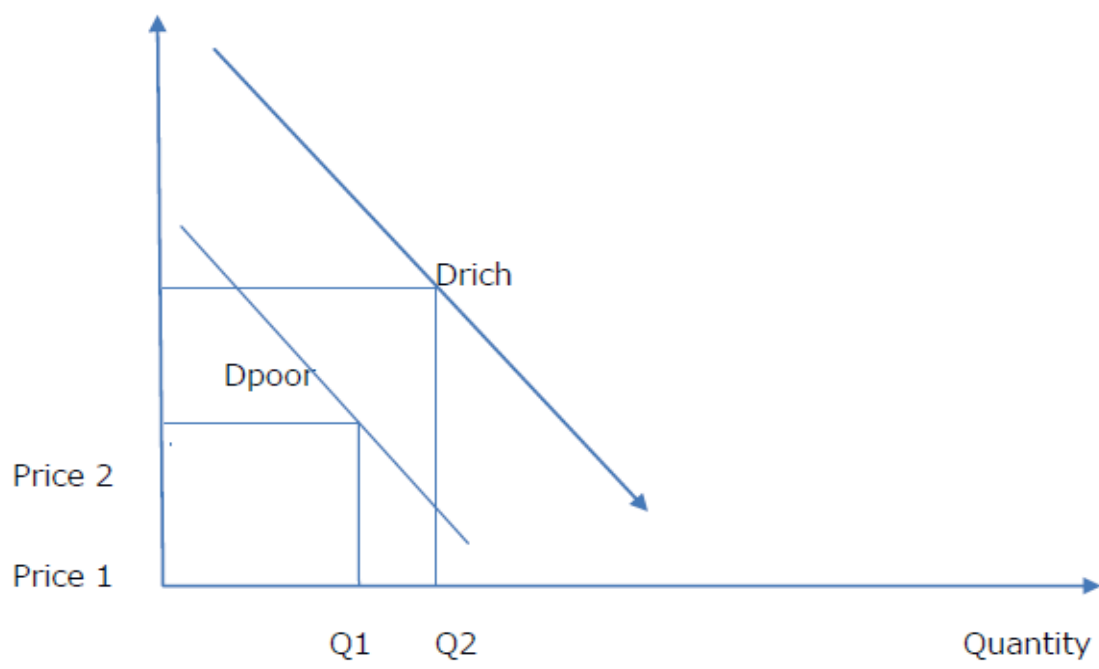

Figure 8. Demand for and Supply of Big Bribes 
Comparing Figure 8 with Figure 7, we arrive at the conclusion that petty corruption would be expected to occur mainly in poor countries, whereas big corruption would expectedly take place predominantly in rich countries. Big corruption cases receive lots of attention, because they are important for market ethics and state integrity. But accusations of big corruption are not always validated by a court—see for instance the many cases in Israel! Big corruption typically involves the market sector with private firms seeking illegal favours in some quid pro quo. The limitation in the CPI to the public sector is arbitrary!

\section{Dynamic Analysis}

Social transformation may reveal itself in the demand and supply of corruption. Thus, when societies develops towards anomie or anarchy, corruption will increase, because it becomes a survival mechanism for both the demand and the supply side—Figure 9 .

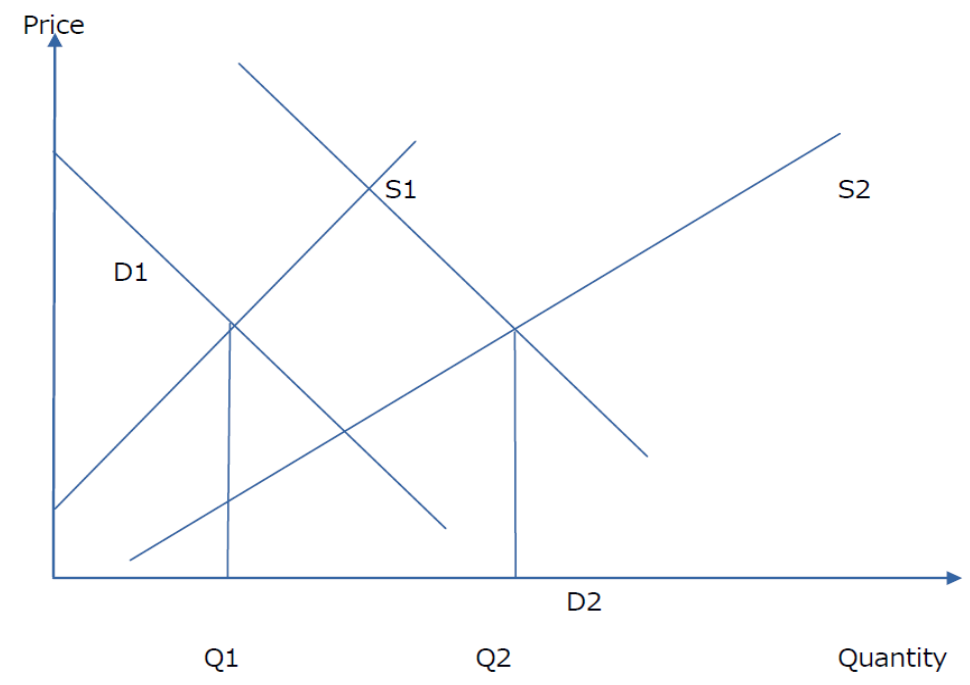

Figure 9. Increasing Demand and Supply of Corruption

When societies lose their firmness of institutions, corrupt practices spread with anomie and anarchy, from Q1 to Q2.

\subsection{Petty Corruption}

Using the demand and supply framework for the analysis of corruption as a binary relationship, one may add a few dynamic remarks to the static pictures above. The demand curve shifts outward when a society faces a crisis, economically or politically. People find that the normal ways of getting goods and services do not function smoothly, which is why they may try to offer an extra payment, monetary or non-monetary ones. There will be more corruption for a higher price in poor societies. If there is a coup d'etat changing the regime towards less institutionalization, the supply curve shifts outwards, as corrupt officials need supplements to their unsafe income, or salaries. The price of corruption goes down and the quantity increases in poor societies. 


\subsection{Big Corruption}

Also, the phenomenon of big corruption is susceptible to dynamic analysis. Suppose there is a change in government from a hard core left one to a right wing government, friendly to the business community. The supply of corruption increases and the curve shifts downward with a new price and quantity.

\section{Remedies}

How to reduce corruption is a much discussed topic. It would seem arguable that corruption could be counter-acted by the legal machinery, but it could not possibly be eradicated in any society. Moralists suggest that altruism, or social capital, is the central remedy. Alas, cheating cannot be fully controlled or completely eliminated. The integrity of the legal system and its legislation is central.

\subsection{Social Trust (Rothstein 2015)}

A few scholars regard corruption is the "cause" of all evil, almost as in a religious theory. They take the reliability and validity of the corruption rankings in Transparency Index CPI for granted, and they correlate these numbers (low for Third World, high for First World) with all bad phenomena. They conclude, like religious believers: Eliminate corruption and the world is saved from evilness! They even go on to suggest a basic remedy, viz. social trust. The problem with the concept of social trust is the same as with corruption in the Transparency Index: too many different connotations and no validated unique denotation. It has even been proposed that the R. Inglehart (1999) individual indicator: Survey question: "Most People can be Trusted" (interpersonal trust or generalized trust) can measure the amount of resistance to corruption in a whole society. This is merely an ecological fallacy (Burnham et al., 2008, p. 41), as it may be the people who answer YES to Inglehart's trust question who engage in corruption!

I would sincerely argue that generalized trust may not be a rational strategy in an environment of infested terrorism. The entire framework of social trust or social capital is a conceptual muddle (Guinnane, 2005; Durlauf, 1999; Stirrat, 2004; Franklin, 2004), despite recent attempts to create a Handbook (Li, 2017). Fukuyama's Trust (1995) is a key text, spelling out social capital theory, but it is too meagre in advancing empirical confirmation, like no regression analysis to support the claim that interpersonal trust increases GDP growth. Theory without data is empty.

\subsection{Wealth Maximization and Corruption (Posner)}

For scholars who believe that justice is economic efficiency more or less, the rejection outright of corruption becomes difficult. Whether wealth maximization, Posner's criterion (Posner, 2004) is to be measured in money or utility, it is easy to contrive many situations were corrupt practices satisfy wealth maximization, especially in cases of petty corruption. One may, e.g., refer to Tullock's (1996) analysis of corruption, which carries a mixed evaluation, as opposed to the standard condemnation in economics (Bhagwati, 1982; Bardhan, 1997; Tanzi \& Davoodi, 1997), looking mainly om macro evidence about negative impact upon economic growth. 


\subsection{Institutional Economics and Corruption}

It is a fundamental assumption in the theory of efficient markets that contracts are transparent, visible and enforceable in the legal machinery. There is absolutely no room for corruption (Cooter \& Ulen, 2011), Why? Two reasons paralleling the above justice distinctions:

a) A priori justice: a market economy operates per definition upon the notions of impartiality, formal equality and transparency. This may be motivated by some theory of justice like, e.g., Rawls' well-ordered society. One of Rawls' precepts of fairness states that offices must be open to all and recruited on the basis of competence. Thus, buying a position would be unjust and constitute a favour against others. This is micro justice that covers for instance jobs and remuneration.

b) Utilitarian reason: Here the arguments are many, claiming that big corruption hurts economic efficiency from several angles like growth, investments and overall competence. There is a large literature, attempting to show by numerous examples that corrupt practices are conducive to bad outcomes, especially at the macro level.

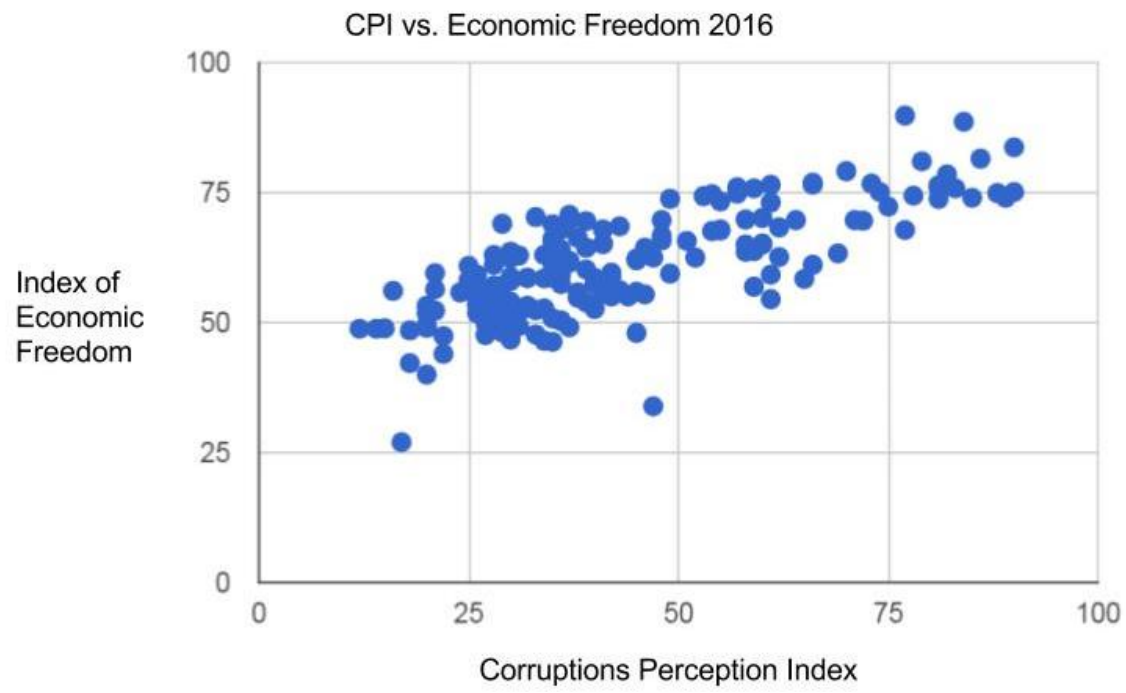

Figure 10. CPI and Economic Freedom Index: $y=0,415 x ; R^{2}=0,58$

Institutional economics considers a low level of corruption as a necessary condition for a vibrant market economy, or crime in general as hurting economic freedom. In Figure 10, this idea is visualized with today's nations, the level of perceived corruption (CPI) being highest among countries with low economic freedom. But big corruption can be large also in capitalist democracies, as the steady flow of "affairs" show. And in poor nations, corruption takes often the form of petty corruption, which is not as significant as moralists tend to claim, 


\section{Looting}

In a principal-agent model of the firm, there is the possibility of looting, meaning that the agent(s) take the entire profit as bonuses. The bonus culture has spread like wild fire the recent decades. And a bonus may now be much larger than the fixed salary of the $\mathrm{CEO}(\mathrm{s})$. It used to be linked to a special or separate performance, but it now tends to be awarded indiscriminately, even when the firm operates at a loss. The bonus culture is an integral part of the immense remuneration packages that $\mathrm{CEO}$ (s) have been able to negotiate for themselves. Economists Hart and Holmstroem (1987) were awarded the Nobel Prize in economics for their analysis of the principal-agent model of agency pay, given a number of assumptions like, e.g., incentive compatibility and the reservation pay, non-observability and costly legal verifiabiliy.

However, they could not show excessive remuneration or foul play. Assuming perfect information, there is a correct remuneration scheme for effort, corresponding to several things like competence, ambition and hours worked and verifiability. But with asymmetric information, the CEO(s) have the upper hand against the shareholders and the work force. If necessary, the $\mathrm{CEO}(\mathrm{s})$ can easily engage in collusion with board members, constantly increasing their fees, on the condition that they receive these incredible pay packages as well as yearly increases whatever the firm result. Is this a form of corruption or cheating perhaps? And the CEOs protect themselves against failure or misfortune (which is which?) with excessive parachutes.

For instance, the giant energy corporation, Vattenfall, plays principal-agent looting with great success every year. Despite deep running losses and sharp capital down-writs, the CEOs receive handsome bonuses every year, which the owner accepts, at times a socialist governments.

\subsection{The Bonus Culture Society}

The remuneration changes for the top elite in the private sector have by and by contributed to the transformation the entire social structure in advanced capitalist democracies. The post-modern social structure is much different from that of the industrial society in the $20^{\text {th }}$ century. Between the excluded and the super rich families, there is a broad set of middle classes who fear social exclusion and envy the super rich, even to such an extent that the temptation of cheating sometimes becomes irresistible.

The enormous incomes of the private sector leaders are transformed into capital and wealth, pushing housing prices into sky-rocketed levels. And the better off middle class hangs on these developments in real estate and financial assets. For other elites in society, the politicians and higher bureaucrats as well as the academics, the only way to afford a living standard like the CEO:s is to procure other incomes, in whatever way. Thus, the bonus culture directly and indirectly increases cheating in society, as is apparent in the augmentation of affairs, calling for judicial counter-action.

The post-modern society with a bonus culture in a vibrant market economy with more and more of NPM is dominated by the rising inequalities in the economy - a development strongly supported by the monetary policy of the Swedish Riksbanken, sticking to negative interest rates for a long time. Take Sweden for instance where in the course of twenty years a welfare state based on a strong public sector 
has been changed in to a welfare society with deteriorating public services and meagre pensions. Sweden is no longer the prime example of a mixed economy, with a 50-50 division between state and market. The redistributive edge of Swedish social democratic society has been undone.

Looting as a strategy by CEOs stems from their information advantage and greed. With asymmetric information, they will charge an extra cost for the shareholders that often constitutes an ocean. Two example, Ericsson and Nokia, were brought down not only because the competitors in telecommunications become too difficult to compete with, despite enormous competitive advantage in the beginning. The huge profits of these two Nordic giants stimulated looting. The truly giant state owned enterprise, Vattenfall, plays principal-agent looting with great success every year. Despite sharp capital down-writs, the CEOs succeed in looting.

\section{Conclusion}

When the concept of corruption is theorized in a more precise manner as a binary relationship, and modelled according to demand and supply, then it is to be found in both poor and rich countries, but it is not the same type of corruption that dominates-petty against big corruption. I hope this argument contain a more nuanced view of corruption than the CPI.

Cheating occurs in all countries. The poor countries have much of petty cheating, which is annoying but not lethal as is cheating in the anarchic societies, like the Saharan countries: Libya, Somalia, Ethiopia, the two Sudans, etc. Big cheating is to be found in both poor and rich societies. In advanced capitalist economies, the bonus culture frames the inequalities and leads some elites in the public sector to cheat in various ways, like faked jobs for friends, misuse of public funds, embezzlements, extravagant use of per diem, gifts, excessive pay for lectures, consulting with huge fee levels, non-economic favours, etc. Why would world politicians like, e.g., Blair, the Clintons and Fillon accept that CEOs outdistance them in affluence and richness? Global consulting, excessive remuneration for speeches and public family employments help a lot.

\section{Sources}

Corruption Perceptions Index. (2015). Transparency International. Retrieved from http://www.transparency.org

Kaufmann, D., Kraay, A., \& Mastruzzi, M. (2010). The Worldwide Governance Indicators: Methodology and Analytical Issues. World Bank: Draft Policy Research Working Paper.

OECD National Accounts data files. (n.d.).

World Bank national accounts data. (n.d.).

World Justice Project. (n.d.). Retrieved from http://www.worldjusticeproject.org

2016 index of economic freedom. (n.d.). Retrieved from http://www.heritage.org/index/ 


\section{References}

Bardhan, P. (1997). Corruption and Development: A Review of the Issues. Journal of Economic Literature, 35, 1320-1346.

Becker, G. (1968). Crime and Punishment: An Economic Approach. Journal of Political Economy, 76, 169-217. https://doi.org/10.1086/259394

Becker, G. (2013). The Economic Approach to Human Behavior. Chicago: University of Chicago Press.

Bhagwati, J. (1982). Directly Unproductive Profit-Seeking (DUP) Activities. Journal of Political Economy, 90, 988-1002. https://doi.org/10.1086/261104

Bowles, R. (1999). Corruption. In Encyclopedia of Law and Economics. University of Utrecht, Holland. Retrieved from http://www.allserv.rug.ac.be

Bowles. (2008). “Corruption”. In P. Burnham, K. G. Lutz, Grant, \& W. Z. Layton-Henry (Eds.), Research Methods in Politics. Basingstoke: Palgrave Macmillan.

Clarke, G., \& Xu, L. (2002). Ownership, Competition and Corruption: Bribe Takers vs. Bribe Payers. World Bank Development Research Group, Policy Research Working Paper.

Clarke, G., \& Xu, L. (n.d.). Ownership, Competition and Corruption: Bribe Takers vs. Bribe Payers. World Bank Development Research Group, Policy Research Working Paper.

Cooter, R., \& Ulen, T. (2011). Law and Economics. New York: Norton.

Durlauf, S. N. (1999). The case "against” social capital. Focus, University of Wisconsin-Madison: Institute for Research on Poverty.

Franklin, J. (2004). Politics, Trust and Networks: Social Capital in Critical Perspective. Families \& Social Capital ESRC Research Group. London South Bank University.

Fukuyama, F. (1995). Trust. New York: Free Press.

Guinnane, T. (2005). Trust: A Concept Too Many. Yale University. Retrieved from http://www.econ.yale.edu/ egcenter/

Hart, O., \& Holmstroem, B. (1987). The Theory of Contracts. In T. F. Bewley (Ed.), Advances in Economic Theory: Fifth World Congress of the Econometric Society (pp. 71-155). Cambridge University Press: Cambridge UK.

Holmes, L. (2015). Corruption-A very Short Introduction. Oxford: Oxford U.P.

Holmstroem, B. (1982). Managerial Incentive Problems A Dynamic Perspective, in Essays in Honor of Lars Wahlbeck, Helsinki: Swedish School of Economics. Review of Economic Studies, 66, 169-182. https://doi.org/10.1111/1467-937X.00083

Inglehart, R. (1999). Trust, Well-Being and Democracy. In E. W. Mark (Ed.), Democracy and Trust. Cambridge: Cambridge University Press.

Klitgaard, R. (1988). Controlling Corruption. Berkeley: University of California Press.

Krueger, A. (1974). The Political Economy of Rent Seeking. American Economic Review, 64(3), 291-303.

Leff, N. (1964). Economic Development Through Bureaucratic Corruption. American Behavioral Published by SCHOLINK INC. 
Scientist, 8(3), 8-14. https://doi.org/10.1177/000276426400800303

Li, Y. (Ed.). (2017). Handbook of Research Methods and Applications in Social Capital. Cheltenham: Edward Elgar.

Martinez-Vasquez, J., \& McNab, R. (2002a). Decentralization and Governance. International Studies Program Working Paper. Andrew Young School of Policy Studies, Georgia State University, Atlanta.

Mauro, P. (1995). Corruption and Growth. Quarterly Journal of Economics, 110(3), 681-712. https://doi.org/10.2307/2946696

Melese, F. (2002). The Problem of Corruption. Free Market, 20(6), 6-8.

Mohtadi, H., Polasky, S., \& Roe, T. (2005). Trade, Information and Corruption: A Signalling Game. Paper presented at American Economic Association meetings in Philadelphia.

Ostrom, E. (1990). Governing the Commons. Cambridge: CUP.

Posner, R. A. (2004). Frontiers of Legal Theory. Cambridge, MA: Harvard U.P.

Rose-Ackerman, S. (1978). Corruption: A Study in Political Economy. New York: Academic Press.

Rose-Ackerman, S. (1994). Reducing Bribery in the Public Sector. In D. Trang (Ed.), Corruption and Democracy. Budapest Institute for Constitutional and Legislative Policy.

Rothstein, B. (2015). Letter to the Royal Swedish Academy of Sciences. See also: "The Tragedy of Economics and the Nobel Prize". Retrieved from https://www.rwer.wordpress.com/2015/10/11/key-member-of-swedish-academy-of-sciences-callsfor-immediate-suspension-of-the-nobel-prize-for-economics/

Shleifer, A., \& Vishny, R. (1993). Corruption. Quarterly Journal of Economics, 108(3), 599-617. https://doi.org/10.2307/2118402

Stirrat, R. L. (2004). Yet another "magic bullet": The case of social capital. Aquatic Resources, Culture and Development, 1(1), 25-33.

Tanzi, V., \& Davoodi, H. (1997). Corruption, Public Investment, and Growth. IMF Working Paper. International Monetary Fund, Washington, D.C.

Tullock, G. (1996). Corruption Theory and Practice. Contemporary Economic Policy, 14(3), 6-13. https://doi.org/10.1111/j.1465-7287.1996.tb00619.x

Wei, S. (1999). Corruption in Economic Development: Beneficial Grease, Minor Annoyance, or Major Obstacle? Paper presented at the Sixth Mitsui Symposium on Economic Freedom and Development, Tokyo.

World Bank. (2001). World Development Report 2002: Building Institutions for Markets. New York: Oxford University Press. 